\title{
MICROHARDNESS OF BULK-FILL COMPOSITE MATERIALS
}

\author{
Katarina Kelić ${ }^{1}$, Sanja Matić ${ }^{1}$, Danijela Marović ${ }^{2}$, Eva Klarić ${ }^{2}$ and Zrinka Tarle ${ }^{2}$ \\ ${ }^{1}$ Private Dental Office; ${ }^{2}$ Department of Endodontics and Restorative Dentistry, \\ School of Dental Medicine, University of Zagreb, Zagreb, Croatia
}

\begin{abstract}
SUMMARY - The aim of the study was to determine microhardness of high- and low-viscosity bulk-fill composite resins and compare it with conventional composite materials. Four materials of high-viscosity were tested, including three bulk-fills: QuiXfil (QF), $x$-tra fil (XTF) and Tetric EvoCeram Bulk Fill (TEBCF), while nanohybrid composite GrandioSO (GSO) served as control. The other four were low-viscosity composites, three bulk-fill materials: Smart Dentin Replacement (SDR), Venus Bulk Fill (VBF) and $\mathrm{x}$-tra base (XB), and conventional control material X-Flow (XF). Composite samples $(\mathrm{n}=5)$ were polymerized for $20 \mathrm{~s}$ with Bluephase $\mathrm{G} 2$ curing unit. Vickers hardness was used to determine microhardness of each material at the surface, and at 2-mm and 4-mm depth. GSO on average recorded significantly higher microhardness values than bulk-fill materials $(\mathrm{p}<0.001)$. The low-viscosity composite XF revealed similar microhardness values as SDR, but significantly lower than XB $(p<0.001)$ and significantly higher than VBF $(p<0.001)$. Microhardness of high-viscosity bulk-fill materials was lower than microhardness of the conventional composite material (GSO). Surface microhardness of low-viscosity materials was generally even lower. The microhardness of all tested materials at $4 \mathrm{~mm}$ was not different from their surface values. However, additional capping layer was a necessity for low-viscosity bulk-fill materials due to their low microhardness.
\end{abstract}

Key words: Composite resins; Bulk-fill; Microhardness

\section{Introduction}

Composite materials first appeared in dentistry in the 1960s with Bowen's discovery of Bis-GMA matrix. Since then, their composition significantly improved, leading to better esthetics, mechanical properties and clinical durability ${ }^{1}$. The greatest disadvantages of conventional composite materials are stress that occurs as a result of polymerization shrinkage and depth of cure limited to approximately $2 \mathrm{~mm}$. In order to overcome these issues, it is recommended to use oblique incremental technique for composite application, by using $2-\mathrm{mm}$ thick layers ${ }^{2-6}$. However, the in-

Correspondence to: Danijela Marovic, $P h D, D M D$, Department of Endodontics and Restorative Dentistry, School of Dental Medicine, University of Zagreb, Gundulićeva 5, HR-10000 Zagreb, Croatia

E-mail: marovic@sfzg.hr

Received October 23, 2014, accepted August 10, 2015 cremental technique can also negatively affect the final outcome of the restoration due to contamination between increments, a weaker bond between layers, and time consumption ${ }^{7,8}$.

The bulk-fill composite resins emerged from the necessity to reduce clinical working time for direct composite restorations while simultaneously keeping a satisfactory degree of conversion and reducing polymerization shrinkage. The biggest advantage of these materials is the possibility of application in 4- $\mathrm{mm}$ thick layers ${ }^{9,10}$. Two groups of bulk-fill composites can be distinguished: (a) low-viscosity materials which are used as base materials and require an additional capping layer, and (b) high-viscosity materials which are sole cavity filling materials.

In conventional composite resins, light attenuation due to light reflection from the material surface, scattering from filler particles and absorption by photoinitiators are limiting the depth of cure to approximately 
$2 \mathrm{~mm}$. Among other factors, filler content and particle size are critical to dispersion of light beam ${ }^{11}$. In contrast to the trend of reducing the filler particle size and producing nanocomposites, fillers in bulk-fill composites are in the macro-filler range, in order to increase translucency of the material and increase the depth of cure $^{12}$. Larger filler particles have lower filler surface area and thus smaller resin-filler interface, which is responsible for the majority of light scattering. Some low-viscosity bulk-fills also have reduced filler content. Besides these modifications, the possibility of 4-mm composite application for Tetric EvoCeram Bulk Fill is a result of the additional germanium-based photoinitiator Ivocerin ${ }^{9,13,14}$.

The depth of cure as established by the ISO 4049 method seems to be overestimated for bulk-fill composites. Instead, it is recommended to use Vickers microhardness measurements at the surface and specific depths for determination of the depth of cure ${ }^{15,16}$. Additionally, the microhardness data for a specific material provide information on its wear, polishability and abrasive effect on antagonist teeth ${ }^{17}$. Positive correlation was found between volume fraction of fillers and Knoop hardness ${ }^{18}$, as well as between mass fraction of fillers and Vickers microhardness ${ }^{19,20}$. Regarding the size of fillers, the composites containing nanofillers were found to exhibit higher microhardness values than conventional composites due to more intimate contact of nanofillers with resin matrix than microfillers ${ }^{20}$.

Considering the modifications in the composition and specifically filler content of the bulk-fill materials, it is necessary to evaluate their micromechanical properties. The aim of this study was to compare microhardness of conventional and bulk-fill materials of high- and low-viscosity at the surface, and at 2-mm and $4-\mathrm{mm}$ depth. The null hypothesis was that there was no difference in microhardness between different groups of materials and between different depths.

\section{Materials and Methods}

In the present study, eight composite materials were used. Four of them were high-viscosity composite materials (Table 1) including three bulk-fill materials: QuiXfil (QF; Dentsply DeTrey GmbH, Konstanz, Germany), X-tra fil (XTF; Voco GmbH, Cuxhaven, Germany) and Tetric EvoCeram Bulk Fill (TECBF; Ivoclar Vivadent AG, Schaan, Liechtenstein), and one nanohybrid composite GrandioSO (GSO; Voco $\mathrm{GmbH}$ ), which served as control. Smart Dentin Replacement (SDR; Dentsply DeTrey GmbH), Venus Bulk Fill (VBF; Heraeus Kulzer GmbH, Hanau, Germany), X-tra base (XB; Voco GmbH) and X-Flow (XF; Dentsply DeTrey $\mathrm{GmbH}$ ) were in the group of low-viscosity composite materials. The first three were bulk-fills, while XF was conventional and served as control (Table 2).

Composite samples were made using a cylindrical Teflon mold with a diameter of $4 \mathrm{~mm}$ and height of 8 $\mathrm{mm}$. Composite material was filled in bulk, condensed within mold by covering with a glass slide and cured with Bluephase G2 curing unit (Ivoclar Vivadent, Schaan, Liechtenstein) for $20 \mathrm{~s}$ in high intensity mode with irradiance of $1120 \mathrm{~mW} / \mathrm{cm}^{2}$. Distance between the light source and the material was $1 \mathrm{~mm}$, which represented thickness of the glass slide. The samples were dry stored in dark for $24 \mathrm{~h}$ in an incubator at 37 ${ }^{\circ} \mathrm{C}$ prior to abrasion to obtain half-cylinders. The Universal type 55 blade (Prvomajska, Zagreb, Croatia) with a diamond plate was used for sample abrasion. Plate dimensions were $150 \times 32 \times 10 \mathrm{~mm}$ and the grit of synthetic diamonds was $160 / 125$. The abraded samples were then polished for $1 \mathrm{~min}$ with commercial toothpaste on a cotton swab. The samples were examined by optical microscope at different magnifications. Magnification was $2.5 \mathrm{x}$ for high-viscosity composites and $1 \mathrm{x}$ for low-viscosity materials.

Vickers hardness method was used to determine microhardness of each material ( $n=5)$. Five microhardness measurements were made for each sample (on the surface, and at 2-mm and 4-mm depth). For surface measurements, indentations were made 50-100 $\mu \mathrm{m}$ from the sample surface, which was in direct contact with the glass slide and the curing unit in order to avoid the oxygen inhibition layer. The Leitz Miniload 2 Microhardness Tester (Leitz, Germany) was used with the load of $200 \mathrm{~g}$. Microhardness was calculated using the following formula: $H V=1.8544 \mathrm{xF} / \mathrm{d}^{2}$, where $\mathrm{d}$ is diagonal of the imprint, and $\mathrm{F}=\mathrm{m} \times \mathrm{g}(\mathrm{g}=9.81 \mathrm{~N} / \mathrm{kg})$.

\section{Statistical analysis}

Normality was tested by the Shapiro-Wilk test and homogeneity of variance was analyzed by Levene's test. Due to the detected variance heterogeneity between different groups of composites, weighted twoway ANOVA was used. Type of composite and mea- 
Table 1. Composition of high-viscosity test materials

\begin{tabular}{|l|l|l|l|l|}
\hline Composite/code & Manufacturer & $\begin{array}{l}\text { Shade/LOT } \\
\text { (expiration date) }\end{array}$ & Resin composition & $\begin{array}{l}\text { Filler amount } \\
\text { (wt\%/vol\%) }\end{array}$ \\
\hline $\begin{array}{l}\text { Tetric } \\
\text { EvoCeram Bulk } \\
\text { Fill (TECBF) }\end{array}$ & $\begin{array}{l}\text { Ivoclar Vivadent, } \\
\text { Schaan, } \\
\text { Liechtenstein }\end{array}$ & $\begin{array}{l}\text { IVA / R04686 } \\
(2015-12)\end{array}$ & Bis-GMA, Bis-EMA, UDMA & $81 / 61$ \\
\hline x-tra fil (XTF) & $\begin{array}{l}\text { Voco, Cuxhaven, } \\
\text { Germany }\end{array}$ & $\begin{array}{l}\text { Universal } \\
/ 1205222 \\
(2014-01)\end{array}$ & Bis-GMA, UDMA, TEGDMA & $86 / 70$ \\
\hline $\begin{array}{l}\text { QuixFil } \\
\text { Posterior } \\
\text { Restorative }\end{array}$ & $\begin{array}{l}\text { Dentsply DeTrey, } \\
\text { Konstanz, }\end{array}$ & $\begin{array}{l}\text { Universal } \\
\text { Germany } \\
(2013-07)\end{array}$ & $\begin{array}{l}\text { UDMA, TEGDMA, di- and } \\
\text { trimethacrylate resins, carboxylic } \\
\text { acid modified dimethacrylate resin, } \\
\text { butylated hydroxytoluene }\end{array}$ & $86 / 66$ \\
\hline $\begin{array}{l}\text { GrandioSO } \\
\text { (GSO) }\end{array}$ & $\begin{array}{l}\text { Voco GmbH, } \\
\text { Cuxhaven, } \\
\text { Germany }\end{array}$ & $\begin{array}{l}\text { A2/1222126 } \\
(2014 / 11)\end{array}$ & $\begin{array}{l}\text { Methacrylate matrix } \\
\text { (Bis-GMA, TEGDMA) }\end{array}$ & $89 / 73$ \\
\hline
\end{tabular}

Bis-GMA = bisphenol A-glycidyl methacrylate; Bis-EMA = ethoxylated bisphenol A glycol dimethacrylate; HEMA = 2-hydroxyethyl methacrylate; TEGDMA = triethylene glycol dimethacrylate; UDMA = urethane dimethacrylate

Table 2. Composition of low-viscosity test materials

\begin{tabular}{|l|l|l|l|l|}
\hline Composite/code & Manufacturer & $\begin{array}{l}\text { Shade/LOT } \\
\text { (expiration date) }\end{array}$ & Resin composition & $\begin{array}{l}\text { Filler amount } \\
\text { (wt\%/vol\%) }\end{array}$ \\
\hline $\begin{array}{l}\text { Venus Bulk Fill } \\
\text { (VBF) }\end{array}$ & $\begin{array}{l}\text { Heraeus Kulzer } \\
\text { GmbH, Hanau, } \\
\text { Germany }\end{array}$ & $\begin{array}{l}\text { Universal } \\
/ 010030 \\
(2014 / 07)\end{array}$ & UDMA, Bis-EMA & $65 / 38$ \\
\hline $\begin{array}{l}\text { Smart Dentine } \\
\text { Replacement } \\
\text { (SDR) }\end{array}$ & $\begin{array}{l}\text { Dentsply DeTrey, } \\
\text { Konstanz, } \\
\text { Germany }\end{array}$ & $\begin{array}{l}\text { Universal } \\
/ 1301001101 \\
(2014 / 12)\end{array}$ & $\begin{array}{l}\text { SDR patented-UDMA, } \\
\text { TEGDMA, Bis-EMA }\end{array}$ & $68 / 45$ \\
\hline x-tra base (XB) & $\begin{array}{l}\text { Voco GmbH, } \\
\text { Cuxhaven, } \\
\text { Germany }\end{array}$ & $\begin{array}{l}\text { Universal } \\
/ 1310503 \\
(2015 / 06)\end{array}$ & Methacrylate resin & $75 / 61$ \\
\hline X-Flow (XF) & $\begin{array}{l}\text { Dentsply DeTrey, } \\
\text { Konstanz, } \\
\text { Germany }\end{array}$ & $\begin{array}{l}\text { A2/1206001145 } \\
(2014 / 05)\end{array}$ & $\begin{array}{l}\text { Di- and multifunctional } \\
\text { acrylate and methacrylate resins, } \\
\text { DGDMA }\end{array}$ & $60 / 38$ \\
\hline
\end{tabular}

Bis-GMA = bisphenol A-glycidyl methacrylate; Bis-EMA = ethoxylated bisphenol A glycol dimethacrylate; DGDMA = diethylene glycol dimethacrylate; HEMA = 2-hydroxyethyl methacrylate; TEGDMA = triethylene glycol dimethacrylate; UDMA = urethane dimethacrylate

surement depth were defined as independent factors. Their interaction was significant and therefore included into the model.

Results were analyzed at the significance level of 0.10 , at which statistical power was satisfactory (80\%) for detecting the effects of medium size (Cohen's $f=0.25)$. The $p$ values were adjusted for multiple comparisons according to the Bonferroni-Holm method. Analysis was performed using the SAS System 8.2 (SAS Institute Inc., North Carolina, USA).

\section{Results}

In the group of high-viscosity composite resins, application of the conventional composite resin GSO resulted in largest mean microhardness values, with maximum mean $\mathrm{HV}$ value of 139 recorded at $2 \mathrm{~mm}$ below the surface (Fig. 1). Regardless of the measuring depth, the mean microhardness recorded for GSO was significantly higher than for QF, TECBF and XTF ( $p<0.001$ all). The lowest values, with HV below 60, 


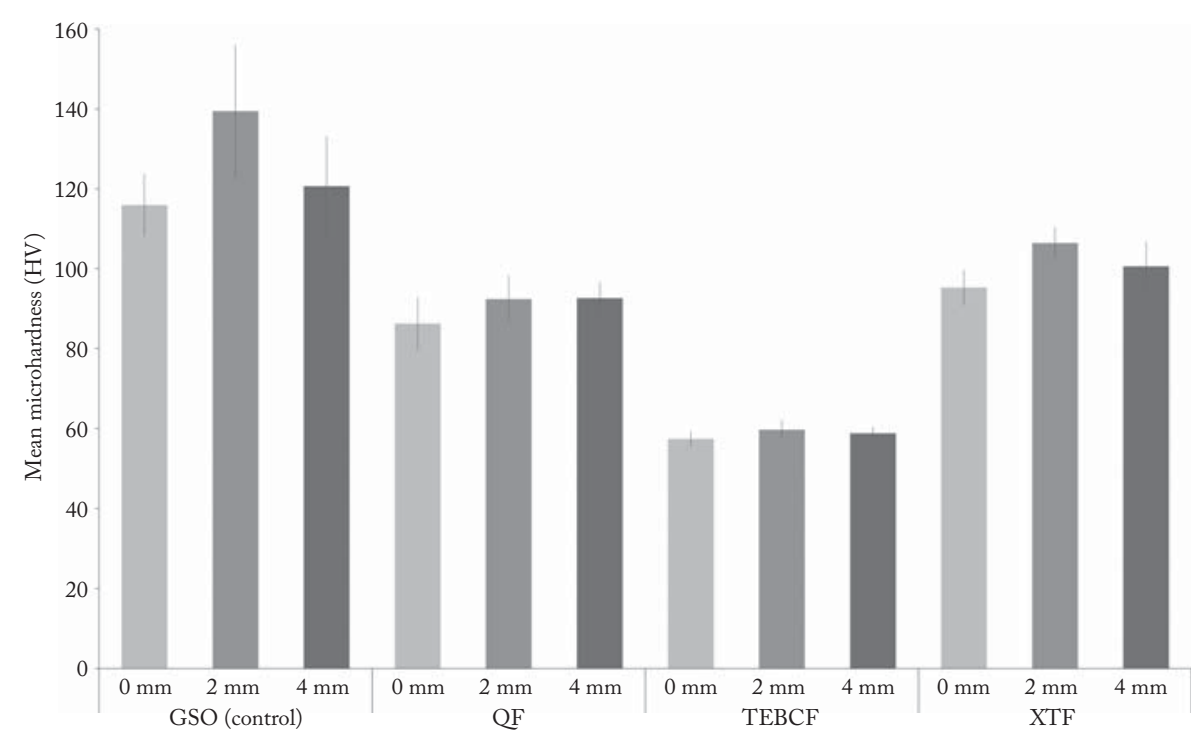

Fig. 1. Comparison of microhardness measurements for different high-viscosity composite resins measured at different depths (0,2 and $4 \mathrm{~mm}$ ).

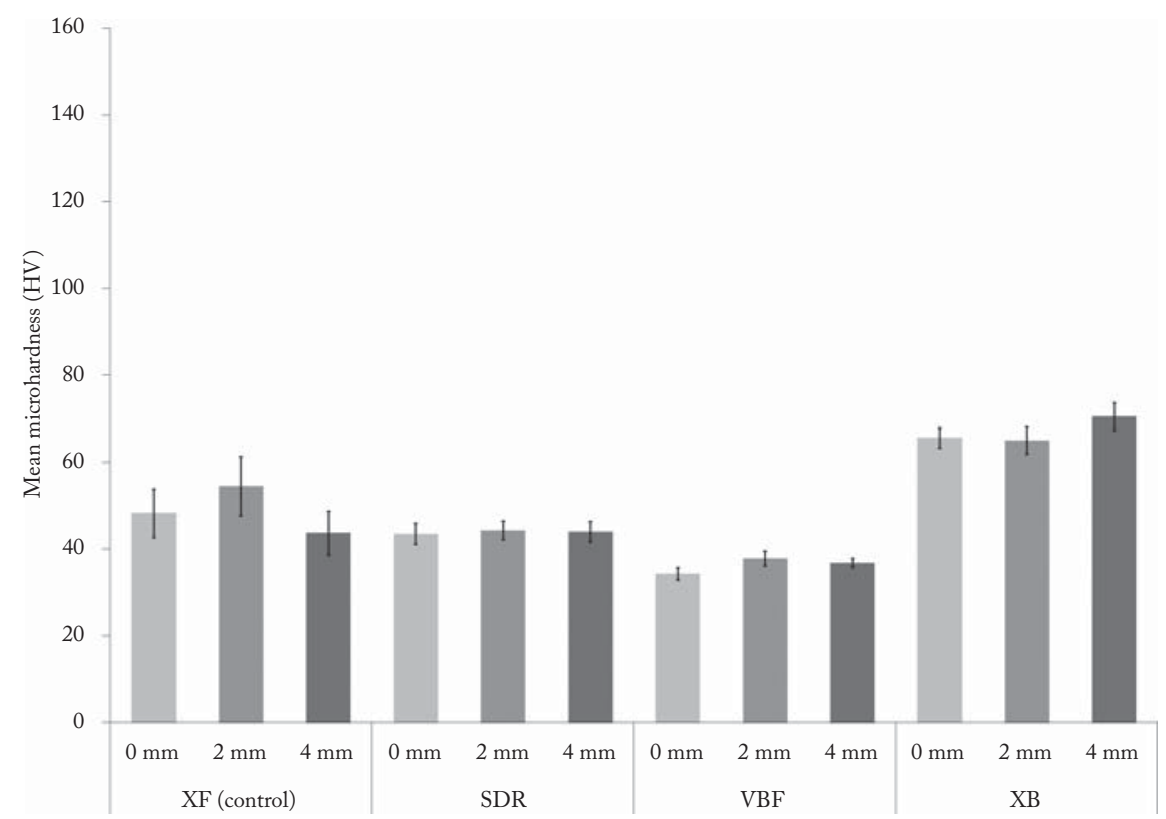

Fig. 2. Comparison of microhardness measurements for different low-viscosity composite resins measured at different depths (0,2 and $4 \mathrm{~mm})$.

were on average recorded for TECBF material. Difference between QF and XTF in surface microhardness was not significant. Within the same material, measurements at $2 \mathrm{~mm}$ and $4 \mathrm{~mm}$ were not significantly different from surface microhardness measurements for all materials except for GSO, which recorded significantly higher values $(\mathrm{p}<0.001)$ at a depth of $2 \mathrm{~mm}$ compared with the other two measurements.
For low-viscosity composite resins, the highest mean microhardness was observed when using $\mathrm{XB}$, with maximum mean $\mathrm{HV}$ value of 71 recorded at 4 $\mathrm{mm}$ below the surface (Fig. 2). Regardless of the measuring depth, application of $\mathrm{XB}$ on average produced significantly higher values than the control material $\mathrm{XF}, \mathrm{SDR}$ and VBF ( $\mathrm{p}<0.001$ all). VBF was the material that recorded lowest mean microhardness values, 
with surface $H V$ value of 34 . Comparison of SDR and $\mathrm{XF}$ did not indicate significant differences, except for 2-mm depth. At this depth, XF and VBF recorded significant increase in microhardness relative to surface measurements ( $\mathrm{p}=0.010$ and $\mathrm{p}=0.096$, respectively). However, for all materials differences between surface microhardness and microhardness measured at $4 \mathrm{~mm}$ below the surface were not statistically significant.

\section{Discussion}

In this study, microhardness of high-viscosity and low-viscosity bulk-fill composite materials was determined on the surface and at $2 \mathrm{~mm}$ and $4 \mathrm{~mm}$, and compared with each other and with conventional composite materials as controls. High-viscosity materials showed higher values than low-viscosity materials at all measured depths. The exception was TECBF, which demonstrated similar microhardness as $\mathrm{XB}$, the material with highest microhardness in the group of low-viscous materials.

According to different investigators, acceptable depth of cure is achieved when hardness of the bottom layer is at least $80 \%$ corresponding to hardness measured at the surface ${ }^{16,21,22}$. In this study, all tested materials satisfied this requirement. Greater variations were not observed in the values on the surface and at 2 or 4 $\mathrm{mm}$. In our previous study ${ }^{23}$, which investigated Knoop microhardness of high-viscosity bulk-fill materials, only 30 -s irradiation with a similar light intensity was sufficient to achieve $80 \%$ of maximum microhardness at 4-mm depth for QF and XTF, but not for TECBF. This difference could be explained by different methodologies used. Namely, in the present study, the samples were grounded and polished, while in the previous study, the hemi-cylindrical molds were used without polishing and hardness testing was performed at the specimen outer resin-rich layer. This likely contributed to the lower microhardness values in the previous study $^{23}$.

Different composite characteristics are affected by filler properties such as size, volume and weight. With increasing filler volume, the flexural strength and modulus of elasticity, as well as hardness, improve $e^{12,24-26}$. Comparison of microhardness of high-viscosity composite materials with their filler volume fraction yielded positive correlation. GSO had the highest microhardness value and the largest volume filler fraction of
73\%. It was followed by XTF, QF and TECBF, with the filler amount of $70.1 \%, 66 \%$ and $61 \%$, respective$1 y^{9,27-29}$. The same pattern appeared when comparing microhardness results of low-viscosity bulk composites with their filler volume. XB with $61 \%$ filler volume had the highest microhardness values, followed by $\mathrm{SDR}, \mathrm{XF}$ and $\mathrm{VBF}$, with filler volume percentages of $45 \%, 38 \%$ and $38 \%$, respectively ${ }^{30-32}$. This also explains the similar values of TECBF from the high-viscosity group to the low-viscosity material XB. Namely, according to the manufacturer's data, TECBF contains prepolymerized filler particles consisting of inorganic glass particles previously polymerized in the resin matrix, which is the cause of lower hardness of fillers, as well as of the entire material ${ }^{9}$. Also, one study reports that the manufacturer's claim that TECBF achieves 4 $\mathrm{mm}$ depth of cure is not true ${ }^{15}$. However, this is not supported by the present study since there was no significant hardness difference at any of the measured depths.

Even though XF and VBF have the same amount of filler, significantly lower microhardness of $\mathrm{VBF}$ compared to XF was demonstrated. This difference could be ascribed to the resin composition. However, the exact composition of the resinous part of XF is not provided, so any potential conclusions could only be speculations. Low mechanical properties of VBF are supported by several other studies ${ }^{12,33,34}$. Unlike most other bulk-fill materials, VBF has not increased the filler particle size, but reduced the total filler amount, which must be one of the major contributing factors to its low microhardness ${ }^{34}$.

Microhardness is also related to the properties of composites such as Young's modulus of elasticity and viscosity. The composite viscosity is correlated with the type of resin matrix. Bis-GMA as the most viscous one is also least flexible, while UDMA and TEGDMA are least viscous ${ }^{35-38}$. The aforementioned correlation was observed in this study, where the highest microhardness values were noted for materials based on Bis-GMA matrix, GSO and XTF in the high-viscosity group, and $\mathrm{XB}$ of the low-viscosity materials.

The GSO, XF and VBF showed lower microhardness at the surface than at $2 \mathrm{~mm}$. This finding is in line with the observations by $\mathrm{Czasch}$ and $\mathrm{Ilie}^{26}$. This agrees with the study which states that the optimal curing is associated with the amount of oxygen present during polymerization ${ }^{39}$. Contrary, Czasch and $\mathrm{Ilie}^{26}$ rejected 
the theory of the influence of oxygen inhibited layer with the fact that the average thickness of this layer is only $20-50 \mu \mathrm{m}$. They report that this phenomenon is related to shrinking of the non-bonded material towards the center of the restorations.

Higher microhardness values correlate with lower material wear, and thus durability and biocompatibility of composite fillings ${ }^{40-42}$. The present study supports the manufacturers' recommendations and previous findings that low-viscosity bulk-fill materials should not be used without the capping layer, as their microhardness is not sufficiently high to withstand masticatory forces. High-viscosity bulk-fills had lower microhardness than the control material GrandioSO, but the values were similar to some conventional nanohybrid composites ${ }^{12}$. Nevertheless, it is recommended to conduct long-term clinical studies in order to assess clinical performance of these materials.

\section{Acknowledgments}

This study was supported by the Croatian Science Foundation (Project 8/31). Ivoclar Vivadent is gratefully acknowledged for the donation of Tetric EvoCeram Bulk Fill and a curing unit.

\section{References}

1. Bowen R. Dental filling material comprising vinyl silane treated fuse silica and a binder consisting of the reaction product of Bis phenol and glycidyl acrylate. 1962; Patent No. 3. 066, 112.

2. Civelek A, Ersoy M, L'Hoteliere E, Soyman M, Say EC. Polymerization shrinkage and microleakage in class II cavities of various resin composites. Oper Dent. 2003;28:635-42.

3. Kwon Y, Ferracane J, Lee IB. Effect of layering methods, composite type, and flowable liner on the polymerization shrinkage stress of light cured composites. Dent Mater. 2012;28:801-9. doi: 10.1016/j.dental.2012.04.028

4. Chikawa H, Inai N, Cho E, Kishikawa R, Otsuki M, Foxton $\mathrm{RM}$, et al. Effect of incremental filling technique on adhesion of light-cured resin composite to cavity floor. Dent Mater J. 2006;25:503-8.

5. Sakaguchi R, Douglas W, Peters M. Curing light performance and polymerization of composite restorative materials. J Dent. 1992;20:183-8

6. Park J, Chang J, Ferracane J, Lee IB. How should composite be layered to reduce shrinkage stress: incremental or bulk filling? Dent Mater. 2008;24:1501-5. doi: 10.1016/j.dental.2008.03.013

7. Abbas G, Fleming GJ, Harrington E, Shortall AC, Burke FJ. Cuspal movement and microleakage in premolar teeth restored with a packable composite cured in bulk or in increments. J Dent. 2003;31:437-44.

8. Sarrett DC. Clinical challenges and the relevance of materials testing for posterior composite restorations. Dent Mater. 2005;21:9-20.

9. Ivoclar Vivadent. Tetric EvoCeram Bulk Fill Scientific Documentation. [Internet]. Schaan: Ivoclar Vivadent; 2013 [cited 2013 Jun 25]. Available from: http://www.ivoclarvivadent. $\mathrm{com} / \mathrm{en} /$ products/restorative materials/composites/tetric-evoceram-bulk-fill.

10. Par M, Gamulin O, Marovic D, Klaric E, Tarle Z. Raman spectroscopic assessment of degree of conversion of bulk-fill resin composites - changes at 24 hours post cure. Oper Dent. 2015;40:E92-101. doi: 10.2341/14-091-L

11. Sakaguchi RL, Powers JM. Restorative Dental Materials. Philadelphia: Elsevier Mosby; 2012.

12. Bucuta S, Ilie N. Light transmittance and micro-mechanical properties of bulk fill vs. conventional resin based composites. Clin Oral Investig. 2014 Nov;18(8):1991-2000. doi: 10.1007/ s00784-013-1177-y

13. Burtscher $\mathrm{P}$, Rheinberger V. Germanium based photoinitiator as an alternative to camphorquinone/amine. IADR. 2008 (Abstract 1611).

14. Moszner N, Fischer U, Ganster B, Liska R, Rheinberger V. Benzoyl germanium derivatives as novel visible light photoinitiators for dental materials. Dent Mater. 2008;24:901-7.

15. Flury S, Hayoz S, Peutzfeldt A, Hüsler J, Lussi A. Depth of cure of resin composites: is the ISO 4049 method suitable for bulk fill materials? Dent Mater. 2012;28:521-8. doi: 10.1016/j. dental.2012.02.002.

16. Bouschlicher MR, Rueggeberg FA, Wilson BM. Correlation of bottom-to-top surface microhardness and conversion ratios for a variety of resin composite compositions. Oper Dent. 2004; 29:698-704.

17. Marovic D, Panduric V, Tarle Z, Ristic M, Sariri K, Demoli N, et al. Degree of conversion and microhardness of dental composite resin materials. J Mol Struct. 2013;1044:299-302. doi: 10.1016/j.molstruc.2012.10.062

18. Chung KH, Greener EH. Correlation between degree of conversion, filler concentration and mechanical properties of posterior composite resins. J Oral Rehabil. 1990;17:487-94.

19. Neves AD, Discacciati JA, Orêfice RL, Jansen WC. Correlation between degree of conversion, microhardness and inorganic content in composites. Pesqui Odontol Bras. 2002; $16: 349-54$

20. Hosseinalipour M, Javadpour J, Rezaie H, Dadras T, Hayati AN. Investigation of mechanical properties of experimental Bis-GMA/TEGDMA dental composite resins containing various mass fractions of silica nanoparticles. J Prosthodont. 2010;19:112-7. doi: 10.1111/j.1532-849X.2009.00530.x

21. Watts D, Amer O, Combe E. Characteristics of visible lightactivated composite systems. Br Dent J. 1984;156:209-15.

22. Moore BK, Platt JA, Borges G, Chu TM, Katsilieri I. Depth of cure of dental resin composites: ISO 4049 depth and micro- 
hardness of types of materials and shades. Oper Dent. 2008; 33:408-12. doi: 10.2341/07-104

23. Tarle Z, Attin T, Marovic D, Andermatt L, Ristic M, Tauböck TT. Influence of irradiation time on subsurface degree of conversion and microhardness of high-viscosity bulk-fill resin composites. Clin Oral Investig. 2015;19:831-40. doi: 10.1007/ s00784-014-1302-6

24. Scougall-Vilchis RJ, Hotta Y, Hotta M, Idono T, Yamamoto K. Examination of composite resins with electron microscopy, microhardness tester and energy dispersive X-ray microanalyzer. Dent Mater J. 2009;28:102-12.

25. Faltermeier A, Rosentritt M, Faltermeier R, Reichender C, Müssig D. Influence of filler level on the bond strength of orthodontic adhesives. Angle Orthod. 2007;77:494-8.

26. Czasch P, Ilie N. In vitro comparison of mechanical properties and degree of cure of bulk fill composites. Clin Oral Investig. 2013;17:227-35. doi: 10.1007/s00784-012-0702-8

27. Voco $\mathrm{GmbH}$. Scientific product information. [Internet]. Cuxhaven: Voco GmbH; [cited 2013 Dec 10]. Available from: http://www.voco.com/en/products/_products/GrandioSO/ VC_84_002610_1110_GB_V.pdf.

28. Voco GmbH. Instruction for use. [Internet]. Cuxhaven: Voco GmbH; [cited 2013 Dec 10]. Available from: http://www.voco. com/en/products/_products/x_tra_fil/x-tra_fil_22spr_049.pdf.

29. DENTSPLY DeTrey GmbH. Instructions for use Quixfill. [Internet]. Konstanz: Dentsply DeTrey GmbH; 2004 [cited 2013 Dec 10]. Available from: https://www.dentsply.co.uk/ Products/Instructions-for-use.aspx.

30. DENTSPLY DeTrey GmbH. Scientific Compendium SDR. [Internet]. Konstanz: Dentsply DeTrey GmbH; 2011 [cited 2013 Dec 10]. Available from: http:/www.dentsplymea.com/ sites/default/files/ScientificcompendiumSDR-2011.pdf.

31. Heraus Kulzer GmbH. Instructions for use. [Internet]. Hanau: Heraus Kulzer GmbH; 2010 [cited 2013 Dec 10]. Available from: http://venusbulkfill.com/media/webmedia_local/media/ pdfs/VenusBulkFillDFU_English.pdf

32. Voco GmbH. Instructions for use. [Internet]. Cuxhaven: Voco GmbH; 2013 [cited 2013 Dec 10]. Available from: http://
www.voco.com/en/products/_products/x-tra_base/GI_x-tra_ base_22spr_0811.pdf.

33. Alrahlah A, Silikas N, Watts DC. Post-cure depth of cure of bulk fill dental resin-composites. Dent Mater. 2014;30:149-54. doi: 10.1016/j.dental.2013.10.011

34. Ilie N, Bucuta S, Draenert M. Bulk-fill resin-based composites: an in vitro assessment of their mechanical performance. Oper Dent. 2013;38:618-25. doi: 10.2341/12-395-L

35. Li J, Li H, Fok AS, Watts DC. Multiple correlations of material parameters of light-cured dental composites. Dent Mater. 2009;25:829-36. doi: 10.1016/j.dental.2009.03.011

36. Khatri CA, Stansbury JW, Schultheisz CR, Antonucci JM. Synthesis, characterization and evaluation of urethane derivatives of Bis-GMA. Dent Mater. 2003;19:584-8.

37. Martim GC, Detomini TR, Schuquel IT, Radovanovic E, Pfeifer CS, Girotto EM. A urethane-based multimethacrylate mixture and its use in dental composites with combined highperformance properties. Dent Mater. 2013;30:155-63. doi: 10.1016/j.dental.2013.11.002

38. Lovell LG, Newman SM, Bowman CN. The effects of light intensity, temperature, and comonomer composition on the polymerization behavior of dimethacrylate dental resins. J Dent Res. 1999;78:1469-76.

39. Uhl A, Michaelis C, Mills RW, Jandt KD. The influence of storage and indenter load on the Knoop hardness of dental composites polymerized with LED and halogen technologies. Dent Mater. 2004;20:21-8.

40. Kim KH, Ong JL, Okuno O. The effect of filler loading and morphology on the mechanical properties of contemporary composites. J Prosthet Dent. 2002;87:642-9.

41. Prica D, Tadin A, Marović D, Katunarić M, Prica A, Galić N. Effects of dental adhesives on micronucleus frequency in peripheral blood lymphocytes in vitro. Acta Clin Croat. 2013 Sep;52:309-15.

42. Kelava N, Lugović-Mihić L, Duvančić T, Romić R, Šitum M. Oral allergy syndrome - the need of a multidisciplinary approach. Acta Clin Croat. 2014;53:210-9. 
Sažetak

\section{MIKROTVRDOĆA BULK-FILL KOMPOZITNIH SMOLA}

\section{K. Kelić, S. Matić, D. Marović, E. Klarić i Z. Tarle}

Svrha istraživanja bila je odrediti mikrotvrdoću visoko-viskoznih i nisko-viskoznih bulk-fill kompozitnih smola i usporediti ih s konvencionalnim kompozitnim materijalima. Četiri visoko-viskozna materijala su testirana, od toga tri bulk-fill: QuiXfil (QF), x-tra fil (XTF) i Tetric EvoCeram Bulk Fill (TEBCF); nanohibridni kompozit GrandioSO (GSO) služio je kao kontrola. Ostala četiri materijala bila su nisko-viskozna, tri bulk-fill: Smart Dentin Replacement (SDR), Venus Bulk Fill (VBF) i $\mathrm{x}$-tra base (XB) te konvencionalni kontrolni materijal X-Flow (XF). Kompozitni uzorci $(\mathrm{n}=5)$ polimerizirani su 20 s polimerizacijskom lampom Bluephase G2. Mikrotvrdoća svakog materijala na površini te na dubini od 2 i $4 \mathrm{~mm}$ je određena po Vickersu. GSO je u prosjeku imao značajno više vrijednosti mikrotvrdoće od ostalih materijala $(\mathrm{p}<0,001)$. Niskoviskozni kontrolni kompozit XF imao je slične vrijednosti kao SDR, ali značajno niže nego nego $\mathrm{XB}(\mathrm{p}<0,001)$ i značajno više nego VBF ( $<$ 0,001). Mikrotvrdoća visoko-viskoznih bulk-fill materijala je niža nego kod konvencionalnog kompozitnog materijala GSO. Površinska mikrotvrdoća nisko-viskoznih materijala je općenito još niža. Mikrotvrdoća svih testiranih materijala na dubini od $4 \mathrm{~mm}$ se ne razlikuje od njihovih površinskih vrijednosti mikrotvrdoće. Dodatni sloj kompozita za prekrivanje nisko-viskoznih bulk-fill materijala je nužan zbog njihove male mikrotvrdoće.

Ključne riječi: Kompozitni materijali; Bulk-fill; Mikrotordoća 